\title{
Rare Occurrence of Microsporidial Myositis Involving Masticatory Muscles
}

Author(s):

Kiran Preet Malhotra, M.D ${ }^{1}$; Hardeep Singh Malhotra, D.M ${ }^{2}$; Rasmi Ranjan Sahoo, D.M ${ }^{3}$; Priyanka Gupta, M.D ${ }^{2}$; Shyam Chand Chaudhary, M.D ${ }^{4}$

Equal Author Contributions:

1 and 2 - These authors contributed equally to this work

Neurology ${ }^{\circledR}$ Published Ahead of Print articles have been peer reviewed and accepted for publication. This manuscript will be published in its final form after copyediting, page composition, and review of proofs. Errors that could affect the content may be corrected during these processes. 
Corresponding Author:

Hardeep Singh Malhotra

drhsmalhotra@gmail.com

Affiliation Information for All Authors: 1. Department of Pathology, Dr Ram Manohar Lohia Institute of Medical Sciences, Lucknow, India; 2. Department of Neurology, King George Medical University, Lucknow, India; 3. Department of Rheumatology, King George Medical University, Lucknow, India; 4. Department of Medicine, King George Medical University, Lucknow, India

\section{Contributions:}

Kiran Preet Malhotra: Drafting/revision of the manuscript for content, including medical writing for content; Major role in the acquisition of data; Study concept or design; Analysis or interpretation of data Hardeep Singh Malhotra: Drafting/revision of the manuscript for content, including medical writing for content; Study concept or design; Analysis or interpretation of data

Rasmi Ranjan Sahoo: Drafting/revision of the manuscript for content, including medical writing for content; Study concept or design; Analysis or interpretation of data

Priyanka Gupta: Drafting/revision of the manuscript for content, including medical writing for content; Major role in the acquisition of data; Analysis or interpretation of data

Shyam Chand Chaudhary: Drafting/revision of the manuscript for content, including medical writing for content; Study concept or design; Analysis or interpretation of data

Number of characters in title: 72

Abstract Word count:

Word count of main text: 100

References: 2

Figures: 2

Tables: 0

Neuroimage Legend Count: 80

Search Terms: [ 120 ] MRI, [ 134 ] Vasculitis, [ 140 ] Fungal infections, [ 144 ] HIV, [ 185 ] Muscle disease 
Study Funding: The authors report no targeted funding

Disclosures: The authors report no disclosures relevant to the manuscript.

A forty-five-year-old lady with acquired immunodeficiency syndrome, on anti-retroviraltherapy (tenofovir disoproxil, lamivudine, dolutegravir), presented with painful mastication and generalized musculoskeletal pain for 6 weeks. She had bilateral hand contractures, with tender masseters, temporalis and gastrocnemii. Absolute eosinophil count was 500 cells/cumm, creatine phosphokinase 66U/L and CD4 count 147 cells/cmm. Cranial MRI showed infiltration of masticatory muscles (Figure 1). Muscle biopsy revealed microsporidial myositis (Figure 2). Microsporidia are obligate intracellular fungi classically affecting immunocompromised hosts. ${ }^{1}$ We present findings of rare microsporidial myositis affecting masticatory muscles. Muscle biopsy is diagnostic and excludes potential clinical (polymyalgia rheumatica, temporal arteritis), medication-related and histologic mimics. ${ }^{2}$

\section{References}

1. Ramanan P, Pritt BS. Extraintestinal microsporidiosis. J Clin Microbiol. 2014 Nov;52(11):3839-44.

2. Patel AK, Patel KK, Chickabasaviah YT, Shah SD, Patel DJ, Narayanappa G, et al. Microsporidial polymyositis in human immunodeficiency virus-infected patients, a rare life-threatening opportunistic infection: clinical suspicion, diagnosis, and management in resource-limited settings. Muscle Nerve. 2015 May;51(5):775-80. 


\section{Figure legends:}

\section{Figure 1:}

\section{Cranial MRI}

Axial sections of cranial MRI depict heterogenous signal intensities involving both masseters (straight arrows), left pterygoid muscle (red curved arrows) and both temporalis muscles (white curved arrows) on FLAIR (A,E) and T2-weighted (B,F) sequences; hyperintense signals in the same muscles are noted on T1-weighted $(C, G)$ sequence with suggestion of contrast-enhancement on T1-Gadolinium-fat-suppressed (D,H) sequence.

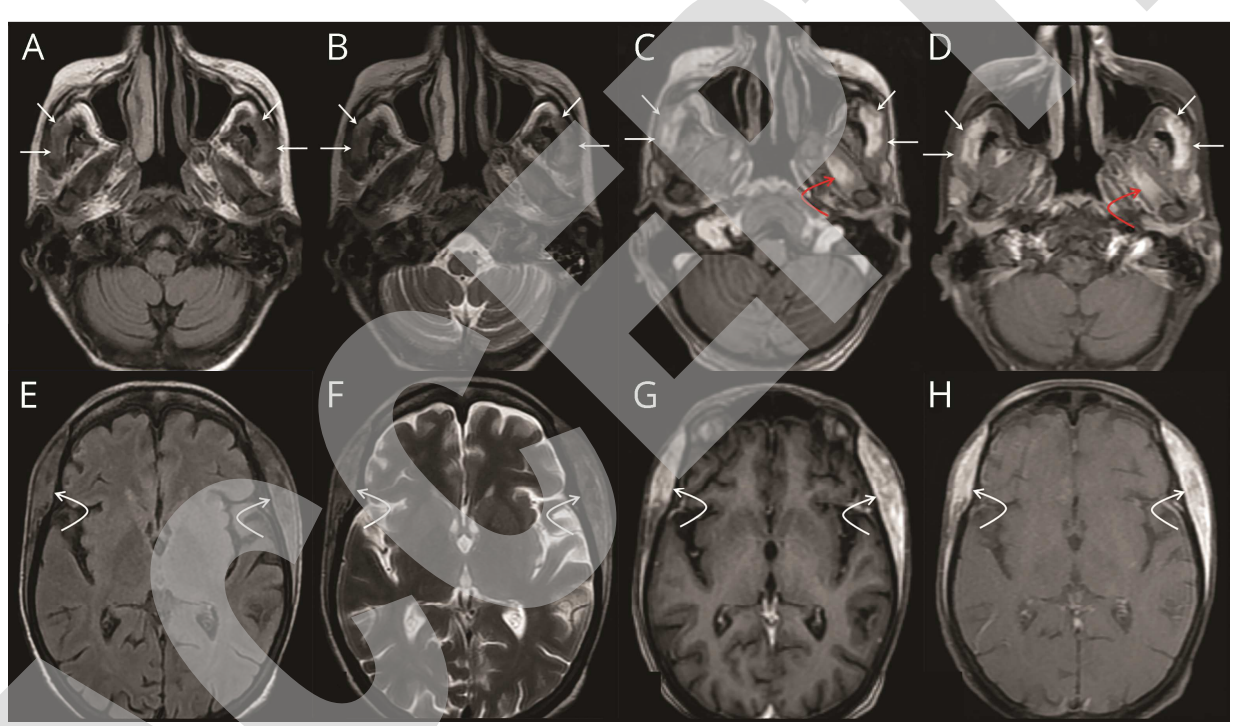




\section{Figure 2:}

Muscle biopsy

Skeletal muscle biopsy showing endomysial lymphocytic infiltrate. Few myofibres show presence of clusters of unstained ovoid, yeast-like bodies consistent with microsporidia (arrows). Hematoxylin \& Eosin, x200
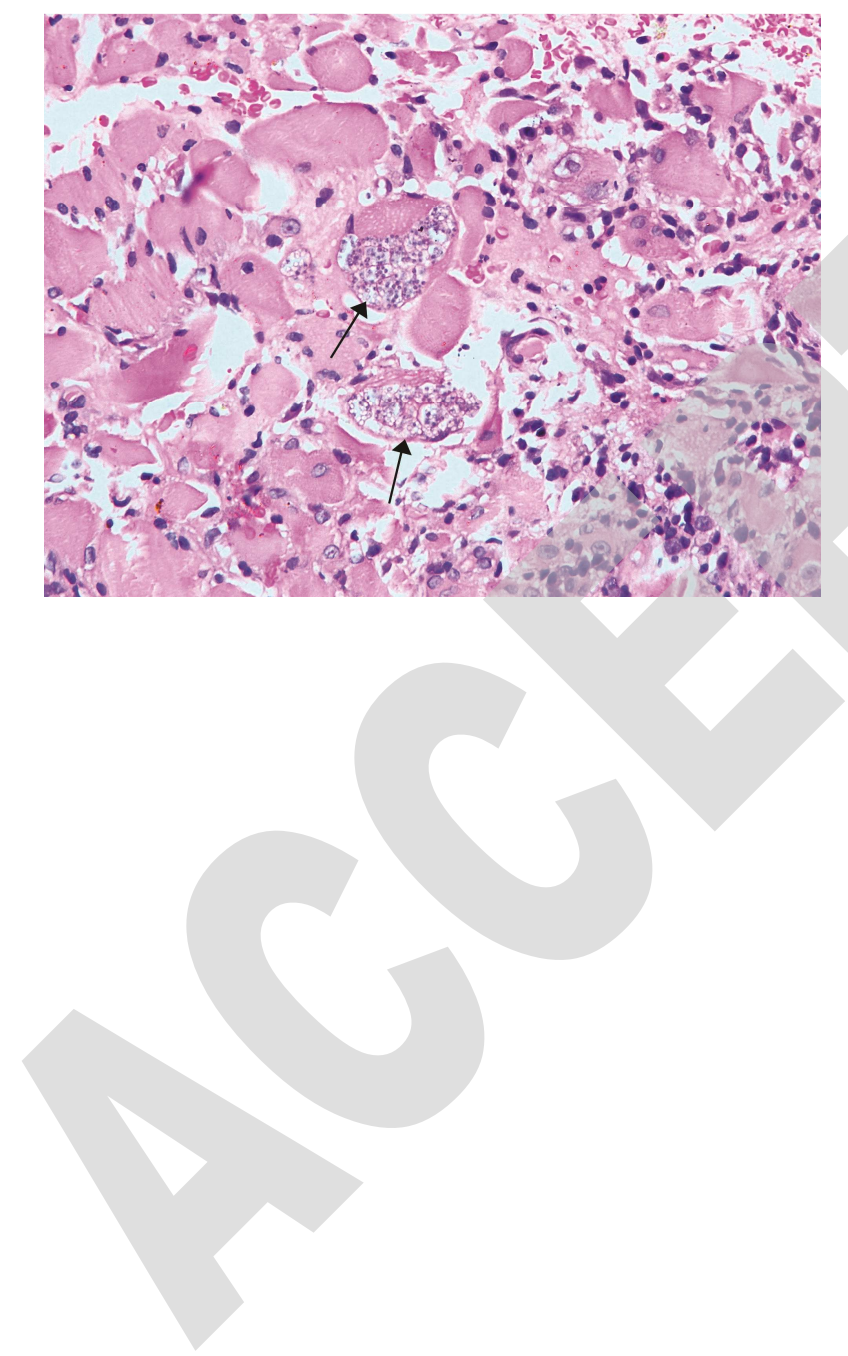


\section{Neurology}

\section{Rare Occurrence of Microsporidial Myositis Involving Masticatory Muscles Kiran Preet Malhotra, Hardeep Singh Malhotra, Rasmi Ranjan Sahoo, et al. \\ Neurology published online December 6, 2021 \\ DOI 10.1212/WNL.0000000000013147}

This information is current as of December 6, 2021

Updated Information \& Services

Subspecialty Collections

Permissions \& Licensing

Reprints including high resolution figures, can be found at:

http://n.neurology.org/content/early/2021/12/06/WNL.0000000000013147. citation.full

This article, along with others on similar topics, appears in the following collection(s):

Fungal infections

http://n.neurology.org/cgi/collection/fungal_infections

HIV

http://n.neurology.org/cgi/collection/hiv

MRI

http://n.neurology.org/cgi/collection/mri

Muscle disease

http://n.neurology.org/cgi/collection/muscle_disease

Vasculitis

http://n.neurology.org/cgi/collection/vasculitis

Information about reproducing this article in parts (figures,tables) or in its entirety can be found online at:

http://www.neurology.org/about/about_the_journal\#permissions

Information about ordering reprints can be found online:

http://n.neurology.org/subscribers/advertise

Neurology ${ }^{\circledR}$ is the official journal of the American Academy of Neurology. Published continuously since 1951, it is now a weekly with 48 issues per year. Copyright (C) 2021 American Academy of Neurology. All rights reserved. Print ISSN: 0028-3878. Online ISSN: 1526-632X.

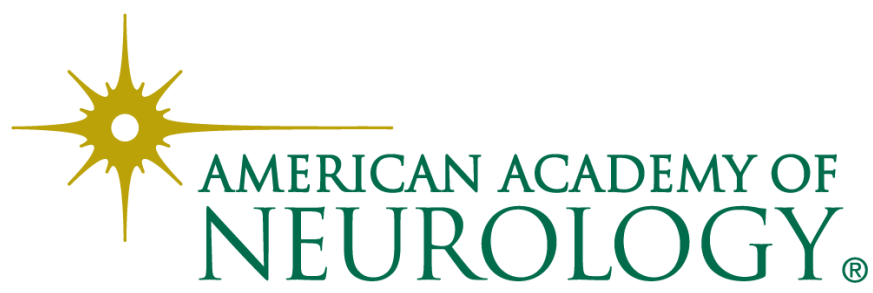

